\title{
The Ethiopian Well-Known Trademark Protection System and Its Implication on Foreign Direct Investment
}

\author{
Romel Moges Mersha \\ Judge, Federal First Instance Court, Addis Ababa, Ethiopia; Former Lecturer and Dean, Wolkite University, \\ School of Law (LL.B, Wollega University, Ethiopia, 2013; LL.M in International Economic and Business Law, \\ Haramaya University, Ethiopia, 2018)
}

\begin{abstract}
Due to the ever increasing trans-border movement, internet connection and globalization, individuals in different corner of the world are becoming easily accustomed to international well-known marks even though the owners of such marks do not produce/supply goods/services within a particular territory. Be this as it may, coupled with the conventional registration and territorial based system that is pursued in respect of the protection of trademarks, the dynamic change of such interaction among the global community have opened a fertile ground for trademark squatters to register and exploit the international well-known marks of others. On the backdrop of this fact, this manuscript investigates the Ethiopian well-known trademark protection system in light of its capacity to promote the interest of the country, in particular in respect of its potential implication on the foreign direct investment flow of the country. The study has made use of primary and secondary sources of data and qualitative analysis to investigate the implication of the regime on the foreign direct investment flow of the country. The finding is that the existing international well-known trademark protection legal framework, which hangs up the special protection of such marks to a future international convention, apart from its potential threat on franchise business and foreign direct investment flow, it is deterring the country from benefiting out of employment opportunities and declaration fees which the country shall consider forth with.
\end{abstract}

Keywords: International well-known trademark, Foreign Direct Investment, Franchise business, Registration, Territorial.

DOI: $10.7176 / \mathrm{JLPG} / 106-01$

Publication date: February $28^{\text {th }} 2021$

\section{INTRODUCTION}

Well-known trademarks, also known as famous brands, are trademarks with great popularity and reputation in a certain area (An Qinghu, 2005). Their function goes far beyond distinguishing sources of products or providers of services; they also represent rich connotations and comprehensive competitiveness (An Qinghu, 2005). The protection of well-known trademarks departs from the basic objective of trademark protection, namely protecting consumers against deception. Rather, it principally aims at preserving the distinctiveness of marks (Latha R. Nair, 2011).

According to WIPO, intellectual property rights (here in after IPRs) are protected through a registration or a grant procedure (Tilahun Esmael, 2013). This will generally mean that they can only be enforced in countries or regions where protection has been established and is in force. This territoriality rule is firmly established in trademark law with the idea that if a mark is not registered with in a national territory, consumers will not encounter it (Tilahun Esmael, 2013). Yet, globalization has rendered this assumption and its resultant rule anachronistic (Tilahun Esmael, 2013). The need to wards the special protection of well-known trademarks is also outsourced in response to the change in modern marketing. Unlike the conventional assumption which associates the protection of trademarks with the proof of the double identity of the mark and goods or services, it is now understood that the reputation of a mark can extend to dissimilar goods or services (Annette Kur, 2014). Thus, many countries are offering special protection for marks that qualify as well-known trademarks through departing from basic trademark principles (Elizabeth Houlihan, 2011).

In view of their special features, literatures and practical experiences are showing that a country's flow of Foreign Direct Investment (here in after FDI) will be negatively affected as a result of the lack of special protection. In this regard, though the working Ethiopian Trademark Registration and Protection Proclamation (here in after Proclamation No. 501/2006) provided rules which potentially protects the property rights of foreign well-known trademarks owners, it subjected their special protection to (an) international convention/s that the country becomes a party in the future. This article will, accordingly, discuss the Ethiopian well-known trademark protection system in light of its implication on the flow of FDI. It has nine parts. While the first section provides an introductory remark; the second part presents a concise review of related literature. The third section goes on to discuss the significance of the study. The fourth section, on its part, expounds statement of the problem of the study. While the fifth and sixth sections consecutively presents objectives and research questions of the study, the seventh and eighth section respectively provides the methodology and the result and discussion part of the study. Finally, the final part presents the finding, conclusion and recommendation of the study. 


\section{LITERATURE REVIEW}

\subsection{WELL-KNOWN TRADE MARKS VIS-À-VIS THE NEED FOR THEIR SPECIAL PROTECTION}

The international jurisprudence on well-known trademarks implies that their protection departs from the following basic trademark principles i.e. ownership right over a trademark is bestowed upon registration (registration) (WIPO,2012); a trademark is protected in respect of the goods/services it is registered (specialty) (WIPO, 2012); a trademark is only effective within the jurisdiction of registration (territoriality) (WIPO, 2012) and a trademark owner shall show up its intent of actual use to benefit out of an effective protection (intent to use). The principle of bad faith that is inculcated in international instruments in defense of certain acts is also another expression of the special protection of such marks (art. 6bis, Paris Convention). In this regard, bad faith is defined as a dishonesty which would fall short of the standards of acceptable commercial behaviors (Kristian Elftorp, 2012). In view of this general definition, lack of genuine use and/ the submission of an application having the knowledge that it is a mark of another with the intent of gaining benefits are considered as specific instances of bad faith applications (Kristian Elftorp, 2012).

The Paris Convention is the first international instrument that makes mention of the special protection of well-known trademarks (Schmidt-Pfitzner, 2009). Accordingly, article $6^{\text {bis }}$ of the Convention diverts from basic trademark principles, namely those of territoriality and registration (WIPO, 2012). In so doing, it imposed an obligation on member States to refuse to register and/ invalidate an already registered mark to be used for identical or similar goods if the mark is well known in that country as being already the mark of a person entitled to the benefits of the Convention. The Agreement on Trade Related Intellectual Properties (here in after TRIPs Agreement) under art. 16(2) and (3) has built upon these exceptional features of well-known trademarks and has expanded the specialty principle of trademarks to goods or services which are even dissimilar.

Due to their rich popularity and loose protection, a great increase in trademark squatting is globally noticed (Ai - Tang Irene Chang, 2012). Trademark squatting (trademark piracy) refers to the act of registration or use of a generally well-known foreign trademark that is not registered in the country or is invalid as a result of non-use (Kitsuron Sangsuvan, 2013). China's and Indonesia's experience in 1990's is explained as a good example in this regard (Christoph Antons et.al, 2015). It is reported by the Indonesian media and practitioners in Jakarta that the prices for such marks raised between US\$10,000 and US\$100,000 in the early 1990s (Christoph Antons et.al, 2015). The squatters, in these countries, have either warehoused the marks without a genuine use waiting for a deal or invested with the same brand without setting a quality and competitive business. For instance, Apple Inc. found itself in an unpleasant surprise with Han Wang Technology when it tried to introduce its wildly popular iPhone into one of the biggest markets in the world, China (Sunny Chang, 2014). The case is when Apple submitted the first application for the iPhone trademark with the Chinese Trademark Office in 2002, they only filed in a subclass for "computers and computer software "(Sunny Chang, 2014). Soon after, a Chinese company called Han Wang Technology registered the iPhone mark under the proper subclass that included "phones and mobile phones"(Sunny Chang, 2014). Apple fought to reclaim the mark, but it ultimately lost the case. It paid \$3.65 million to Han Wang Technology for the rights to the trademark (Sunny Chang, 2014). Another example of trademark squatting is Pfizer's trademark on "Viagra" in China. A Chinese company, the Guangzhou Viamen Pharmaceutical Company, had first registered the "Weige" trademark which is a transliteration of Pfizer's trademark of "Viagra" in China (Daniel Chow, 2012). Pfizer, as a brand owner, cannot use the Chinese transliteration "Weige" as a trademark in China. Pfizer does not own the "Weige" trademark which Viagra is best known in China and in the entire Chinese-speaking world (Daniel Chow, 2012). The battle over the "Weige" trademark in China meant that the market for Viagra in China has been almost entirely lost to counterfeiters and pirates. The decision of Pfizer ultimately was that it decided to take back its FDI which it was, otherwise, willing to invest and expand its products into China, presumably because the amount required by Guangzhou Viamen Pharmaceutical Company is hardly commensurate with the potential profit it is to earn via its FDI.

In order to tackle the above problem, a number of countries are, thus, proclaiming specific legislation that is different from ordinary trademarks (Enzo Baiocchi, 2014). Apart from setting aside the traditional theory of territoriality and registration, they are enacting specific legislation that offers protection against dilution and bad faith applications. The Federal Trademark Dilution Act in U.S; the Brazil Patent and Trademark Office Resolution No. 107 (here in after BPTO Resolution No. 107) in Brazil and the Rules on recognition and protection of well-known trade marks (2003) in China are good illustrations in this regard (An Qinghu, 2005). Depending upon the existing situation in their economy, these countries have set factors that are used to determine the well-known aspect of a mark and relevant sector of the public in concern together with the requisite level of knowledge that can uplift a mark as well-known (Elizabeth Houlihan, 2011). An owner who successfully proves the well-known aspect of his/her mark will be afforded a special protection. For instance in Brazil, the recognition of a mark as well-known affords the mark a special protection in all market segments i.e. a protection for non-similar goods/acts of services for ten-year period. However, for the extended right an applicant enjoys, s/he is required to pay 17,500 USD as a declaration fee (Enzo Baiocchi, 2014). 
WIPO has adopted a Joint Recommendation Concerning Provisions on the Protection of Well-Known Marks (here in after WIPO Joint Recommendation). It ,among others, considers factors such as the degree of knowledge or recognition of the mark in the relevant sector of the public; the duration, extent and geographical area of any use, advertising or publicity of the mark; the record of successful enforcement of rights in the mark and the value associated with the mark as relevant to determine the well-known aspect of a mark in a concerned country (art. 2(1)b, WIPO Joint Recommendation).On the other hand, actual and/or potential consumers; persons involved in channels of distribution and business circles dealing with the type of goods and/or acts of services to which the mark applies are set as pertinent categories of persons to determine relevant sector of the public (Para 2.1, 2.8, Explanatory notes to WIPO Joint Recommendation).

The pertinent legislation that deals about the status of protection of well-known trademarks in Ethiopia is Proclamation No. 501/2006, and the most relevant stipulation is article 23. The reading of the article infers us that a well-known trademark that is protected by an international Convention to which Ethiopia is a party is protected provided that it is a trademark of a person that is a national of a state party to the Convention or is domiciliary or has a real and effective industrial establishment in a State party to the Convention. The most important potential international agreements, in this regard, are the Paris Convention and the TRIPS Agreement and Ethiopia has not ratified both agreements (Tilahun Esmael, 2013). As such, owners of well-known trademarks don't have the aforementioned special protections in Ethiopia.

One pertinent fact that forces Ethiopia to offer a special protection is the franchise business boom in Africa (Kendal H. Tyre, 2009). South Africa is an excellent example how franchising can be used in Africa to create jobs quickly and effectively by helping local people set up Small and Medium Enterprises under a franchise system (Babette Marzheuser, 2010). According to the African Development Bank, Africa is praised to have a promising potential to exploit this form of doing business (Babette Marzheuser, 2010). Nonetheless, exploiting such business, inter alia, requires the protection of intellectual property rights in general and well knowntrademarks in particular.

\subsection{THE NEXUS BETWEEN THE PROTECTION OF WELL-KNOWN TRADEMARKS AND FDI}

The setting up of franchise business is motivated or de-motivated depending upon the level of protection offered for well-known trademarks in a host country. Accordingly, the manner as to how a country's well-known trademark protection system treats either of the following trademark issues will have an effect on the boost of franchise business. First is the issue as to whether it offers protection for unregistered well-known marks (Michele Lee, 2003). The traditional theory of territoriality requires an individual to apply for protection over each jurisdiction. This requirement has assisted trademark squatters to manipulate by registering a well-known mark originating in a foreign jurisdiction before the foreign trademark owner penetrates in a potential market. Thus, a system that either ex officio avoids the registration of a mark which is similar to unregistered wellknown mark or that validly permits the invalidation of a copy cut shall be established. The second issue is how far a country's well-known trademark protection system gives an anti-dilution protection (Michele Lee, 2003). Intellectual Property Rights (here in after IPRs) are often the basis for the inherent value of a franchise business, and trademarks as an element of franchise helps to convey authenticity and exclusivity (David J. Kaufmann, 2001). Authenticity and exclusivity of a trademark is preserved not only by proscribing the use of others trademark over similar goods/services, but also through legally prohibiting their uses with businesses of a completely different line. The threat of dilution is very strong as businesses often realize the potential benefits of manipulating the public perception associated with the goodwill of a business (David J. Kaufmann, 2001).

The implication of a loose well-known trademark protection system is that it deters business persons from penetrating into a foreign market. Franchisors may wish to penetrate into a local market through known franchisee firms. However; if they believe that all possible franchisors with good truck record are already squatted, they may not be willing to invest despite the existence of a good investment pull factor. After all, the brand owner may wish to invest with his/her own brand. In such occasion, the consequence of a loose international well-known trademark protection system is that either the brand owner will be denied from penetrating in the market where his or her brand is registered by squatters or $\mathrm{s} /$ he will be forced to pay a huge sum of money to reclaim his or her brand back (Sunny Chang, 2014).

\section{SIGNIFICANCE OF THE STUDY}

This study via assessing the Ethiopian well-known trademark protection system's ability of compromising cross cutting interests i.e. the interest of local business persons, FDI flow in the form of franchise business and the rights of well-known trademark owners will provide certain inputs for the legislature.

\section{STATEMENT OF THE PROBLEM}

Proclamation No. 501/2001, under article 23(1) inter alia, provides that well-known trademarks that are protected under international conventions that Ethiopia is a member will be accorded protection if a mark is 
well-known in Ethiopia. Considering the fact that the most important potential multi-lateral international agreements, in this regard, are the Paris Convention and the TRIPs Agreement, one can safely assume that the pertinent provisions of the proclamation protecting well-known trademarks will be put in to effect when Ethiopia joins these instruments. As Ethiopia is not a party to these international agreements to date, wellknown trademarks do not have any special protection in Ethiopia.

The lack of special protection of such marks makes them prone to trademark squatting and is resulting in a correlated problem of trademark warehousing. This will have a negative effect on the country's FDI flow, in particular on the boost in franchise business.

\section{OBJECTIVE OF THE STUDY}

\subsection{GENERAL OBJECTIVE}

The general objective of this study is to review the Ethiopian well known-trademark protection system and investigate its implication on the country's FDI flow.

\subsection{SPECIFIC OBJECTIVES}

In particular, the study seeks to:

$>$ investigate the legal regime governing well-known trademark protection in Ethiopia , and thereby show the legal gaps for the legislature or other appropriate government organ for a legislative response,

$>$ investigate the potential implication of the Ethiopian's well-known trademark protection system on the country's FDI flow, in particular on the boost in franchise business

\section{RESEARCH QUESTIONS}

The study intends to answer the following questions i.e.

$>$ What shall be the position of Ethiopia in offering a special protection for well-known trademarks?

$>$ Does the current well-known trademark protection system pose a potential threat on the country's FDI flow?

\section{METHODS AND METHODOLOGY}

The study method employed is chiefly qualitative, mainly because the data collected is used to expound the research problem. It has made use of both primary and secondary sources of data. While the primary sources of data are gathered via interviews conducted with respondents in Ethiopian Intellectual Property Office (here in after called EIPO) and federal trademark agents, secondary sources of data are gathered from different published and unpublished sources like books, journals, cases and other relevant internet sources. As such, in depth interview is conducted with three respondents out of the eight trademark experts in EIPO who were selected by using stratified sampling based up on their work experience (two experts with 5 years' experience, one with 1 year and the other with 10 years' experience) and five trademark agents out of the forty three active federal trademark agents who were selected by using simple random sampling. The collected primary and some secondary sources of data are qualitatively analyzed to investigate the implication of the Ethiopian well-known trademark protection system on the country's FDI flow, in particular on the boost on franchise business.

\section{RESULT AND DISCUSSION}

\subsection{THE ETHIOPIAN WELL-KNOWN TRADEMARK PROTECTION SYSTEM AND ITS IMPLICATION ON FDI}

The problem of the Ethiopian international well-known Trademark Protection System is associated with the hanging up of their special protection to an international convention that the country becomes a member in the future. The effect is that well-known trademarks fail to have special protection in Ethiopia.

One important decision that shows the gaps of the Ethiopian well-known trademark regime in promoting franchise business and FDI has been passed in the recent past. The case pertains to the dispute of Six Continent's Hotels Inc. vis-à-vis Crown Hotel. The case commenced when Six Continent's Hotels, Inc., the Parent Company of International Crown Plaza, requested EIPO to register and protect the trademark "Crown Plaza Hotels and Resort" (Appellant Crown Hotel vis-à-vis Respondent Six Continents Hotels Inc., 2015). The request for local protection came following the Franchise and Hotel Management Agreement with Tsemex. In the process of registering the mark, the owner of the local Crown Hotel, Mrs. Zewditu, opposed its registration. Nonetheless, the Trademark and Industrial Design Protection and Development cluster of EIPO decided for the registration of the international trademark through justifying the construction of a five star hotel promotes the preamble of Proclamation No. 501/2006 which associates the role of trademark protection with up grading trade and industrial development of the country. The local Crown Hotel appealed to the Appellate Committee and the High Court respectively, but both confirmed the decision of the cluster on a different ground. This has not stopped the owner of the local Crown Hotel to appeal to the Federal Supreme Court, Cassation Bench.

The Cassation bench stressed on the nexus between trademark protection laws and investment promotion 
laws of the country. In its chain of reasoning, the bench centered in justifying when and how an adjudicative/judicial organ is required to take into consideration the overall goal of the protection of trademarks elucidated in the preamble. Even though the bench recognized the taking into concern of such overall goals, it has equally provided the need to take care of the rights of a registered trademark owner. In this regard, the bench urged that one shall not be snatched his/her right of priority on the sole reason that investment shall be promoted. In connection with the stipulation under the preamble, the court opined that it merely shows how the protection of trademarks will have a positive impact in promoting investment. This decision shows that unregistered international well-known trademarks are not protected in Ethiopia, and owners of such marks can be easily deterred from bringing their FDI when need arises.

A second case that shows how the current international well-known trademark protection system is incubating trademark squatters is the case pertaining to the international mark "IN-N-OUT Burger" (Bewket Abebe, 2013). To begin with, the mark is a mark of a company which was established in USA in 1948 and has been working in fast food since then. In 2011, a local business person ventured on the business with a trade name IN-N-OUT Burger. Having heard the News from its USA customers that a fast food business is going on with such mark in Ethiopia, the international well-known trademark owner applied for the registration of its mark in 2012 (Bewket Abebe, 2013). Although the owner of the local business person opposed the registration, EIPO, without citing its legal base, declined the opposition reasoning that a well-known trademark is protected regardless of registration. After securing the right, the owner of the international well-known trademark took the case to the High Court claiming that the defendant is attaining unlawful enrichment via registering and using its trademark. The High Court where the case is submitted through reasoning out that the defendant is entitled with all set of rights as a result of its effective registration of its trade name ruled that there is no infringement (Interview with Ato Tamerat Assefa, Authorized Federal Trademark Attorney and Agent, (Dec. 25,2017 at 5 a.m.)).This is a case with a clear aspect of trademark squatting, but so performed in a different aspect from those which are familiar. This is because the trademark squatting is conducted by registering and using others wellknown trademark as a trade name.

In the interviews conducted with federal lawyers and trademark agents, all the respondents explained that local business persons do not register marks because they lack signs that can be used as a trademark. Via citing the above cases and bad faith applications they came across in their experiences, they urged that the country shall establish a system that protects unregistered well-known trademarks from bad faith application as owners of international well-known marks offer priority to register their marks in countries with better potential markets (Interview with Ato Tamerat Assefa et.al, Authorized Federal Trademark Attorney and Agent, (Dec. 25, 2017 at 5 a.m.).

In another interview with the Legal Research and Mainstreaming Senior Expert in EIPO, the current international well-known trademark protection system is identified as a very potential threat to FDI (Interview with Ato Dereje Tsebu, Legal Research and Mainstreaming Senior Expert, EIPO (Dec. 25, 2017 at 4 a.m.). With regard to the quest posed about the scope of the problem of trademark squatting in the country, the expert illuminated that the office has come up with the fact that shows an individual holding more than 3000 trademarks. The intention, here, is not to engage on business with all such marks, but to wait for a deal up until the real owner or potential licensees show an interest to venture in the market, he explained. This will put foreign owners, who will plausibly be investors too, to negotiate with their own marks. In the interviews conducted with Federal trademark agents and trade mark experts in EIPO on different occasion and place, the interviewees have revealed that international well-known marks such as Nokia, Seven Star, Pegio, Caltex, Water Pool and Geepas have all been submitted for registration by trade mark pirates. They expounded that such marks were submitted in view of either blocking the owners of such marks from venturing with their FDI or from selling their original product in the market.

Although the implication of the current international well-known trademark protection system on the country's flow of FDI will be much visible when the country's economy grows up and calls for owners of foreign well-known trademarks and franchisees and initiates trademark squatters to come out from their hidden hovel for a deal, this effect seems to have been early understood in Ethiopia. In this respect, the Reporter, a reputable Newspaper in Ethiopia, via citing the above cases, has recently gone through the scenario in the following manner "From literature, one of the biggest setbacks for developing countries to attract FDI which is critical to create jobs and facilitate technology transfer is this very issue of intellectual property right. MNCs from the western hemisphere are quite sensitive to their property right (Dawit Endashaw, 2017)." This assertion definitively backs up the finding of the article which urges for a robust well-known trademark protection system, without of course compromising local interests.

\section{FINDING, CONCLUSION AND RECOMMENDATION 9.1 FINDING}

In light of the objective, the following are the findings of the research i.e. 
Unlike the international jurisprudence, international well-known trademarks do not have special protection in Ethiopia i.e. unregistered marks are not offered protection and the protection for registered marks even do not extend to dissimilar goods/services. The finding of the research, in this regard, reveals that the legal loopholes are resulting in a rampant act of trademark ware housing and deterring the country from reaping further income and employment opportunities that arises in the process of determining the mark as wellknown.

$>$ Unlike countries' experience discussed in the paper, Ethiopia does not have a specific legislation that is concerned about the determination and protection of well-known trademarks. However, the finding of the research from the experiences reveal that through wisely crafting the factors that are used to determine the well-known aspect of a mark and the amount of service fee that is to be paid for the extended right the owner of a mark with well-known status is to enjoy, Ethiopia can benefit if it can enact a specific legislation that is concerned about the determination and protection of well-known trademarks.

$>$ Offering a special protection for well-known trademarks and a boost on franchise business and FDI has positive relationship. International experience, national cases and data acquired from interview reveals that trademark squatters are warehousing trademarks without an actual intent to use. As the registration and warehousing of others well-known trademarks by trademark pirates create a monopoly over the mark, the finding of the research reveals that such acts can bar a potential FDI or franchise business to penetrate in the market when need arises.

\subsection{CONCLUSION}

The article has investigated the Ethiopian well-known trademark protection system, in particular its implication on the country's flow of FDI. Article 23(1) of Proclamation No. 501/2006 which declares the protection of wellknown trademark that is protected by an international Convention to which Ethiopia is a party reveals that Ethiopia does not offer any special protection for well-known trademarks, mainly because the country is not a party to any of the international convention the provision is referring.

Despite the hanging up of the special protection of international well-known marks to a future international convention, the article urges the country to afford a special protection irrespective of being a party to any of such conventions. Apart from the revenue and employment opportunities that can be acquired in declaring a mark as well known, there are other benefits such as enhancement of fairness of competition that impulses the country to extend such protection. Above all, the failure of affording a special protection through affecting the setting up of franchise businesses, it potentially poses a threat on the country's flow of FDI.

\subsection{RECOMMENDATION}

$>$ The hanging up of the special protection of international well-known trademarks to an international convention to which the country becomes a party in the future fails to promote the interest of the country. Thus, they shall be offered the following special protections i.e. a protection regardless of registration, a protection over dissimilar goods/services and a protection from bad faith applications, provided that owners of the marks comply with the procedures established and fulfill the factors to be considered.

$>$ The determination and protection of well-known marks requires a specific legislation. Such legislation needs to specifically address the determination and types of protection afforded for owners of such marks. Accordingly, it shall, among others,

$\checkmark$ Establish factors that are used to determine the well-known aspect of a mark. It shall enlist the factors that are used to set the extent of knowledge required and the relevant sector of the public. In particular, the country is better off in extrapolating the WIPO Joint Recommendation as it sets objective relevant factors and is proved to be effectively adopted by a number of countries. The factors shall neither be lenient so that any ordinary mark that claimed such recognition shall be protected nor stringent so that that a mark that shall otherwise be protected as well-known be pushed from being protected.

$\checkmark$ Apart from setting the application fee that is to be paid for an application to register the mark, the legislation shall set a fee that shall be paid for the wider rights that an applicant entertains if his/her mark is declared as well-known. The amount of the fee shall be commensurate with the potential economic benefits that a mark owner gains if his/her mark is declared as well-known. Thus, it, in particular, needs to consider the length of time that such declaration preserves a mark as well-known.

$>$ The well-known trademark regime needs to be crafted in such a way that it avoids the potential threat of the regime on the country's FDI flow, in particular on the boost on franchise business. Accordingly, well-known trademark owners who manage to prove the well-known status of their mark shall be entitled with a right to apply the ex officio cancellation or at any time invalidation of a registered mark which was based up on bad faith. 


\section{REFERENCES}

\subsection{CASE, LAWS AND INTERNATIONAL AGREEMENTS}

1. Appellant Crown Hotel vs. Respondent Six Continents Hotels Inc., Federal Supreme Court Cassation Bench, File No. 117013, July 1, 2015.

2. Final Act Embodying the Results of the Uruguay Round of Multilateral Trade Negotiations, Marrakesh Agreement Establishing the World Trade Organization, signed at Marrakesh (Morocco), April 15, 1994; Annex IC, Agreement on Trade-Related Aspects of Intellectual Property Rights (here in after called TRIPS), reprinted in The Results of the Uruguay Round of Multilateral Trade Negotiations-The Legal Texts, 1-19, 365-403, GATT Secretariat, Geneva (1994)

3. Trademark Registration and Protection Proclamation No. 501/2006, Federal Negarith Gazetha, $12^{\text {th }}$ Year No. 37, (2006)

4. Paris Convention for the Protection of Industrial Property of March 20, 1883, as revised at Brussels on Dec.14, 1900, at Washington on June 2, 1911, at The Hague on November 6, 1925, at London on June 2, 1934, at Lisbon on Oct. 31, 1958, at Stockholm on July 14, 1967, and as amended on Sept. 28, 1979

5. WIPO, Joint Recommendation Concerning Provisions on the Protection of Well-Known Marks, Standing Committee on the Law of Trademarks, Industrial Designs and Geographical Indications, adopted by the Assembly of the Paris Union for the Protection of Industrial Property and the General Assembly of the WIPO, Thirty-Fourth Series of Meetings of the Assemblies of the Member States of WIPO, Geneva, September 20 to 29 , 1999

\subsection{BOOKS AND JOURNAL ARTICLES}

1. Ai - Tang Irene Chang (2012) Whether a Trademark qualifies as a Well-Known Mark? - Application of Bad Faith in Determining the Degree of Well-Knownness. NTUT J. of Intellectual Property Law \& Management 1, 53-93

2. Annette Kur (2014) Trade Marks Function, Don't They? CJEU Jurisprudence and Unfair Competition Principles. Max Planck Institute for Innovation and Competition, 434,453

3. An Qinghu (2005) Well-Known Marks \& China's System of Well-Known Mark Protection. Trademark Reporter 95.3, 705-725

4.Babette Marzheuser-Wood (2012) Franchising in Africa: Legal and Business Considerations

5.Christoph Antons et.al (2015) Well-Known Trademarks, Foreign Investment and Local Industry: a Comparison of China and Indonesia. Deakin Law Review 20.2, 186-219

5.DanguolèKlimkevičiūte (2010) The Legal Protection of Well-Known Trademarks and Trademarks with a Reputation: The Trends of the Legal Regulation in the EU Member States. MykoloRomerioUniversitetas, Social Sciences Stud 3.7, 230-256

6. David J. Kaufmann (2001) Understanding Franchising Business \& Legal Issues.

7. Elizabeth Houlihan (2011) Famous Marks in Countries

7. Enzo Baiocchi (2014) Protection and Regulation of Highly Renowned Trademarks - a Brief Overview of Recent Developments in Brazilian Trademark Law in Jonathan Hoffmann et.al (eds.), IPO-WTO Colloquium Papers, 23-31

8. KitsuronSangsuvan (2013) Trademark Squatting. Wisconsin International Law Journal 31.2, 253,258

9. Michele Lee (2003) Franchising in China: Legal Challenges when First Entering the Chinese Market. American University International Law Review 19. 4, 949-1007

10.Schmidt-Pfitzner (2009), Trademark, in: Peter-Tobias Stoll et.al (eds.) WTO-Trade-Related Aspects of Intellectual Property Rights, vol.7, martinusnijhoffpublishersleidenboston,304-319

11. Sunny Chang (2014) Combating Trademark Squatting in China: New Developments in Chinese Trademark Law and Suggestions for the Future. Nw. J. Int'l L. \& Business 34, 337-358

12. Tilahun Esmael (2013) protection of well-known trademarks in Ethiopia: a comparative treatise under the trademark proclamation. Haramaya Law Review, 1.2, 89-137

13. WIPO (2012, $3^{\text {rd }}$ edition), the Enforcement of Intellectual Property Rights: a Case Book.

\subsection{THESIS AND UNPUBLISHED WORKS}

1. Robert W. Emerson (2015) Franchise Marks: International Trademark Registration Costs and Consequences. Available at https://papers.ssrn.com/sol3/Delivery.cfm/SSRN_ID2975781_code86449.pdf?..1.last accessed at January 1, 2017.

2. Kristian Elftorp (2012) Bad faith trade mark applications in China: a threat to foreign investment? Unpublished Masters Thesis, Jonkoping University available at https://www.diva .portal.org/.smash/get/diva2:540119/FULLTEXT01. . last accessed at05/01/2017 


\subsection{INTERNET SOURCES}

1. Bewket Abebe(September 15,2013) an IN-N-OUT Dispute over Foreign Trademark. Fortune Newspaper available at https://addisfortune.net/articles/an-in-n-out-dispute-over-foreign-trademarks/ last accessed at 15 December 2016

2. Dawit Endashaw (September 2, 2017) Uprising Trademark Debacle, the Reporter, available at https://www.thereporterethiopia.com/content/rising-trademark-debacle Last accessed at15 December 2016

3. Kendal H. Tyre. June 29, 2009. Franchising sector in Egypt receives financial boost, (Nixon Peabody LLP

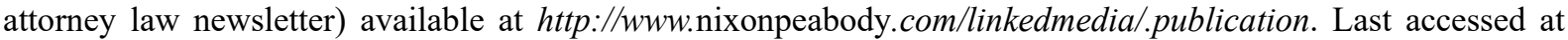
08/08/2016 